\title{
SSTR5 Gene
}

National Cancer Institute

\section{Source}

National Cancer Institute. SSTR5 Gene. NCI Thesaurus. Code C28639.

This gene plays a role in G protein-coupled receptor signal transduction and stimulates

DNA synthesis and cellular proliferation rates. 